\title{
The Spectacle of Death
}

\author{
By: Carina Cino
}

\section{Introduction}

Nuremburg, mid-sixteenth century. Arsonist Lienhard Deürlein continues to drink hard from a bottle of wine. He is paraded through the streets, muttering curses at the people he passes throughout his entire procession. Having reached the gallows, he hands the bottle to the chaplain while he urinates in the open. As his sentence is read aloud, Deürlein concedes he is prepared for death, but has one final request: he asks of the judge to allow him to fence and fight with four of the guards. His request is aptly denied. He takes the bottle from the chaplain and begins again to drink. With tried patience, the executioner, Meister Frantz Schmidt, does not wait for Deürlein to say the words, "Lord, into thy hands I commend my spirit.” Instead, he interrupts Deürlein's drink with a swing of his sword, striking off Deürlein's head. ${ }^{1}$

In the early modern era, execution was the punishment fitting of many crimes. Although their frequency varied from year to year and country to country, executions became a spectacle of retribution that resulted in death. Executions, like that of Lienhard Deürlein, were dramatic performances filled with suspense, horror, and excitement. Their public nature drew large crowds to witness the hand of justice at work. The spectacle of punishment that emerged from this publicization of execution was used by state powers to demonstrate authority and provide justice to the people it represented. The pageantry of execution amended the wrongdoings of the criminal to the community while allowing the state to maintain control of the public's response towards crime. Control, in an era

\footnotetext{
${ }^{1}$ Joel F. Harrington, “Lord Judge, Have I Executed Well?" Slate Magazine, 30 May 2013, accessed 24 November 2017.
} 
where many political and religious changes were occurring, was very important for state powers to successfully run a country.

\section{Rectifying the Wronged}

Criminals of a community were individuals caught committing crimes against the state, village, or community member. Their actions were in violation of laws set forth by state, local, or religious powers. Whether the crime committed was against the state, individual, or the church, execution could be a warranted punishment. If the execution was conducted in secret or with minimal witnesses, the community that had been offended was not afforded the understanding that justice had been served. By publicly displaying a criminal's execution, the people received a sense of justice, honour was restored to the city, and the community was saved in the eyes of Christ. The pageantry of execution gave meaning to the public.

In an age of vendettas, it is not surprising that killing a person was commonplace when seeking vengeance for an individual wronged. Feuds offered a stage for unequal struggles, treacherous attacks, and maiming to occur frequently. Provided these feuds served to uphold family honour through revenge, "assailants were unashamed and third parties showed no indignation." ${ }^{2}$ However, the sixteenth century saw a major shift in moral thought and action, as well as a suppression of vendettas and feuding legality. This was in part because of increasing state organization and the influence of religion in Protestant and Catholic countries. ${ }^{3}$ It was no longer moral or legal for the individual to

\footnotetext{
${ }^{2}$ Pieter Spierenburg, Violence and Punishment: Civilizing the Body Through Time (Cambridge: Polity Press, 2013), 2.

${ }^{3}$ Ibid.
} 
take revenge that led to murder, but if the state carried out the action, there would be no contention.

State-sanctioned executions thus became an alternative to the actions carried out through duelling and feuds. Instead of a person murdering the individual who had done them wrong, they could entrust the state to carry out their revenge. However, simply putting the criminal to death would be too easy. In doing this, the state would essentially be committing murder and the sense of revenge for the community or individual wronged would be absent. The outright killing of criminals would lose the relevance of the punishment and become more about the criminal than the community. With the addition of punishment as a preamble to more serious crimes, the public supported the state's choice for the death of criminals who conducted more heinous crimes as an appropriate alternative to vendettas. People were appeased when revenge could be carried out upon one that had wronged them.

Revenge often involved an individual committing similar actions against the person who had wronged them or their family. In an "eye for an eye" fashion, the pain inflicted upon the wrongdoer was meant to make him "pay" for his actions. Personal revenge, separate from that conducted by mafia or mob groups, was often not about money; it was more about making the wrongdoer understand how it felt to have the same actions imposed upon him. This was a key element of revenge that provided individuals involved in feuds with the sense of justice that the wrongdoer had been dealt with in a way that was equal to pain inflicted upon him or his family. As mentioned previously, the simple killing of a criminal would not provide this same sense of retribution. Punishment of serious criminals, before their death, thus became a major part of public executions. 
The punishment that occurred before hanging or beheading often recreated the crime committed. Often, "mutilation and exhibition of the body followed codes that called particular attention to the parts of the criminal's body that had carried out the crime." ${ }^{4}$ The objective was to have the criminal understand what it meant to be a victim of their crime, similar to the goals of pain infliction during feuds and duels. Thieves had their hands cut off, arsonists were burned, and beatings and broken bones were typical for those who committed abuse. Other punishments given to criminals included being dragged behind a horse, lashes across the back, and being cut by hot pincers. ${ }^{5}$ In public opinion, the punishment should fit the crime.

The executioner mentioned earlier, Meister Frantz Schmidt, was an executioner in Nuremberg from 1578 to 1617 . His diary outlines every execution he performed, detailed frequently with individuals' names, their crimes, and the punishments conducted before death. Entry 43 is dated 26 January 1580 . In this entry, Schmidt outlines the punishment of three child murderesses:

Margaret Dorfflerin (50 years old) from Ebermannsstatt, Elizabeth Ernstin (22 years old) from Anspach, Agnes Lengin (22 years old) of Amberg, three child murderesses. The woman Dorfflerin, when she brought forth her child in the garden behind the Fort, left it lying alive in the snow so that it froze to death. Ernstin, when she brought for her child alive in Master Behcimb's house, herself crushed its little skull and locked the body in a trunk. But the woman Lengin, when she brought forth her child alive in the house of a smith, throttled it and buried it in a heap of refuse. All three beheaded with the sword as murderesses and their heads nailed above the great scaffold, no woman having been beheaded before this at Nuremberg. I and the two priests, namely Master Eucharius and Master Lienhardt Krieg, brought this about, as the bridges

\footnotetext{
${ }^{4}$ Nicholas Terpstra, "Body Politics: The Criminal Body between Public and Private," Journal of Medieval and Early Modern Studies 45, no. 1 (2015): 7.

${ }^{5}$ Archivio di Stato di Bologna, Gonari delle Giustizie seguite in Bologna del 1050-1730.
} 
were already prepared, because they should all three have been drowned. ${ }^{6}$

When Schmidt states "they should all three have been drowned," he was referring to the just punishment the three women should have endured. Drowning left the victim helpless as they struggled for air that does not come. This resembled the inability children had to save themselves when they were left in the snow to freeze to death, or when their skulls were being crushed in. In this case, the state provided partial justice to the people through the executions of the murderers. The women were justly killed at the hand of a professional, but their initial death was not befitting of the crime. As an attempt to remedy this, the executioner and the priests nailed the heads of the women "above the great scaffold," a final punishment for the dead. The infliction of punishment or torture before the execution, or sometimes after in the case of Dorfflerin, Erntsin, and Lengin, provided the public with a feeling that justice was equated with the treatment of criminals and the way in which they died.

The public nature of the execution served another purpose - to restore honour to the community. Honour was a very important element of early modern society across Europe. An individual's honour, or dishonour, reflected directly upon his or her family and the surrounding community. The porous nature of a community's communication networks made dishonour a major social stigma. Everyone in the city knew of the dishonourable action or occupation one engaged in, making life extremely difficult. "Judicial penalties branded the guilty person, either in reputation or with a physical mark" that often represented the crime they committed. Tongues of blasphemers would

\footnotetext{
${ }^{6}$ Franz Schmidt, A Hangman's Diary: Being the Journal of Master Franz Schmidt, public executioner of Nuremberg, 1573-1617 (Montclair, NJ: Patterson Smith, 1973).

${ }^{7}$ Edward Muir, Ritual in Early Modern Europe (Cambridge: Cambridge University Press, 2005), 116.
} 
be pierced and hands of thieves cut off. Additionally, blinding, cutting off ears, whippings and brandings were not uncommon mutilations. These marks served to warn others of the penalty of criminal action.

For many crimes, however, it was not enough to allow an individual to continue to walk the streets of the city branded. The dishonour of capital crimes warranted capital punishment, which in turn would cleanse the city of the dishonour brought about by the criminal. Meister Frantz Schmidt outlined the punishment of a woman, Barbara Wissnerin, for the crimes of theft and prostitution in Nuremberg during the sixteenth century:

...due to great unchastity, multiple thefts and breaking and entering [she] has already been in the Loch [the city jail] eight times. She was banished many times, and has perjured herself [i.e., and come back into Nuremberg] and was beaten in the Loch. She was publicly burned through the cheeks, and her first two fingers were chopped off... She was let out of the city after swearing an oath, and warned under penalty of death not to come in to the city again. Whereupon she came in again and was caught at theft. Now on her own confession her day of execution is set for next Thursday, the first of March. For the said punishment she will be taken from life to death in water. ${ }^{8}$

Although not initially charged with greatly dishonourable crimes, Wissnerin was forced out of the city to cleanse Nuremberg of the dishonour she carried. Her return brought dishonour to the city. The only way to be certain her dishonour would cease to taint the city was to have her executed. For Wissnerin and capital criminals, dying meant the end of social dishonour. The stigma would no longer haunt the community or the individual. Public executions allowed the community to experience the release of dishonour and the cleansing of the community. They were witnesses of the event, verifying its truth and validating the city's return to honour.

\footnotetext{
8 "Punishment of a Woman for Theft and Prostitution, Germany $16^{\text {th }}$ century," in Early Modern Europe, 1450-1789, ed. Merry Wiesner-Hanks (Cambridge: Cambridge University Press, 2006).
} 
The religiosity of the era was not absent from the ritual of execution. The public nature of punishment also served to provide salvation to the community. Initially, the execution took place at the scene of the crime. The local populous saw the execution as a warning about the consequences of committing such a crime, as well as a cleansing through the shedding of blood. ${ }^{9}$ As governments became more centralized and stable, executions were moved to permanent locations in cities. Even with the move to permanent location, the ritual of execution continued to evoke the Catholic ideology of salvation through Christ. According to the Catholic faith, Jesus died on the cross for the salvation of man. Before He died, however, Jesus was paraded through the streets of the city of Golgotha to Calvary Hill. In a similar fashion, criminals were paraded through the streets of communities before making their way to the set places of execution. Although the processions represented the same concept, the ways they were conducted varied from country to country: "in Venice the procession usually returned to the scene of the crime where the sentence was publicly read and the condemned mutilated; in London the criminal walked or was carted three miles though the center of the city from Newgate prison to the gallows; in Paris the hangman and a priest accompanied the culprit in a chariot from prison to the town hall." $" 10$

The procession in Bologna was similar to that of Venice. The prisoner was led first from his cell to the second floor of the Palazzo del Modestà, overlooking the Piazza Maggiore. Here his crimes were read aloud to the square below. He then began the walk to the field of Mercato del Monte. Along the way, the prisoner might stop for Mass or return to the place where his crimes were conducted. Figure 1.1 shows a modern-day map

\footnotetext{
${ }^{9}$ Muir, 117.

${ }^{10}$ Ibid.
} 
of where the beginning and the end of the procession in Bologna would have been in the sixteenth century. The route taken is difficult to determine, as each criminal had a different procession in terms of locations visited due to the nature of their crimes, but the beginning and end of the procession remained the same. ${ }^{11}$

Cesare d'Assaro and Giovani Vincenzo del Mauro were two men who experienced a more intricate procession. The men were from Naples and had committed capital crimes in Bologna on 27 October 27 1599. They robbed the bank of Ghelli of 15,000 scudi, shot an archebus at the notary of the Procuratore, and killed a butcher by the name of Taddeo Abelli. They proceeded to try and flee to Hungary, but the Ghelli chased and caught the two men in Vienna and brought them back to Bologna. For their punishment, the two were taken by cart through the city to the Piazza Grande and given two tanagliate, or slashes. They were then carted to the Chiavature al Banco di MS Taddeo Ghelli and cut twice more. Next, they were dragged to the Casa del Procuratore Grati, the house of the Procuratore they shot with the archebus, and slashed twice again. The next stop was the gate beneath the butcher's they had killed where they received two more slashes. Each stop was intended to force the men to remember the crimes they committed and the pain they inflicted. In Ringhiera, their right hands were cut off as punishment for their thievery. Finally, they were hanged and quartered. ${ }^{12}$

The parades undertaken by criminals were alterations of the Catholic Stations of the Cross. Instead of walking as Jesus did, persecuted for man's salvation, the criminal walked the footsteps of the Messiah in order to be saved. It is fitting that the Crucifixion story places Jesus between two criminals, also being executed for capital offenses. The

\footnotetext{
${ }^{11}$ Nicholas Terpstra, The Art of Executing Well: Rituals of Execution in Renaissance Italy (Kirksville, Mo.: Truman State University Press, 2008), 40.

${ }^{12}$ Archivio di Stato di Bologna.
} 
presence of criminals reinforced the notion that even the "unworthy" could be saved in Christ. The convicted committed a crime worthy of death, but before death, his soul must be saved by walking the path of Christ. The re-enacting of the Stations was completed when the criminal reached the place of execution, the Golgotha of his city. There he was "crucified" in Christ, cleansing him of his sins and providing him everlasting salvation. The two criminals in the Crucifixion story represent honour and privilege, on the right side of Christ, and debasement and condemnation on the left. ${ }^{13}$ Although the criminal was saved by the honour of Christ, he was not free of the judgement passed on him. The combination of these two understandings is what allowed for the duality of justice and salvation through one perverted individual.

The salvation of the community was also an important facet of these "executions in Christ." Communities in early modern Italy were generally tightly knitted groups of people where everyone knew each other. The watchful eyes of neighbours, especially in Italian communities, ensured people conducted themselves appropriately. As a result, the criminal activities of individuals were often considered a reflection of the entire community. Executions were traditionally seen as a removal of the criminal from a civil society that did not recognize the actions of the prisoner as representative of the community's conduct or honour. "Those who died were those whom the community had not rallied around to save and reintegrate through commutation, composition, informal peace agreements, acquittals, and the like." ${ }^{" 14}$ The community cast out the rebel for the survival of the group. Church discipline at this time was aimed at maintaining purity amongst the community of believers. In order to uphold the virtue of the community in

\footnotetext{
${ }^{13}$ Mitchell B. Merback, The Thief, the Cross and the Wheel: Pain and the Spectacle of Punishment in Medieval and Renaissance Europe (London: Reaktion, 2001), 23.

${ }^{14}$ Terpstra, "Body Politics," 37.
} 
God's eyes, the weak links needed to be cast out. Criminals were these weak links, seen as imperfections of the community body. The march to the gallows in the way of Christ allowed the community to cleanse itself of the impure by sending the tainted individual to ask for God's forgiveness. The community did their duty in bringing the criminal to Christ. In this way, the soul of the community was protected and order restored in the eyes of the faithful.

The execution also provided a cleansing of the community from the bad or evil residing within it. The individual himself was seen as an evil member of society, but his soul was the bigger issue. The uncleanliness of the criminal soul meant a tainting of his family and those around him, including the entirety of the community. Tudor monarchs used the concept of God as ruler to control trials and executions, passing off public punishments as "divinely sanctioned." ${ }^{15}$ In these sanctions, God saw the truth and preserved the innocent while convicting the guilty. Once determined guilty, the convict's soul was targeted for cleansing through faith and acceptance that his conviction was the Will of God. The body was unable to be cleansed by the same means as the soul, so it was alternatively dealt with by execution. Evil was removed from the soul and the destructiveness of the human body was physically removed from the community. Catholic ideology professed that the goal was for all souls to go to Heaven; execution provided means for the cleansing of the soul to go to Heaven and the community to be rid of the body.

From a community perspective, the execution of criminals was beneficial in many ways. The suppression of vendettas and vengeance seeking forced the public to rely on

\footnotetext{
${ }^{15}$ Karen Cunningham, "Renaissance Execution and Marlovian Elocution: The Drama of Death," PMLA 105, no. 2 (1990): 209.
} 
state-sanctioned executions for justice. The punishment inflicted upon a criminal, if properly administered, provided justice and a sense of relief for the wronged members of the community. Their revenge was carried out in a manner that reflected the pain of the victim in a vindicating way. The public nature of this justice was a method of honour restoration for the people. Once again, a community was seen as honourable, having eliminated and cleansed the dishonour from its streets. By parading the criminal around before his death, the community attempted to save the soul of the individual, as well as that of the community, in the name of Christ. The removal of evil from a city returned its community to its original order and allowed it to resume its "good-natured living" in the eyes of God. These understandings of the execution were a manipulation of the community by state powers. Execution gave the people what they wanted: a way to achieve vengeance and salvation at the same time. The question then becomes about the purpose, about what state authorities aimed to achieve from the publicization of execution.

\section{Control in an Age of Disorder}

European communities experienced much change through the early modern era, especially after the religious reformation that began in 1517. People wanted more control over their daily lives, which would in turn take control away from state authorities. As a response to this public outcry, states began strengthening their authority through policing of communities. ${ }^{16}$ However, policing was not enough to maintain control of the public: execution helped to compensate where the power of the police failed. The publicity

\footnotetext{
${ }^{16}$ Steven Hughes, "Fear and Loathing in Bologna and Rome: The Papal Police in Perspective," Journal of Social History 21, no. 1 (1989): 97.
} 
executions gained throughout the early modern era painted the state in a positive light for many Europeans. The state became the arbiter of conflict by maintaining social order through mercy and conviction, appearing as protectors of what was important to the community, and exerting their power through the frequency of punishment differently during different time-periods. It was important for state governments to maintain a balanced image of justice and mercy in order to maintain control.

Upholding social order was extremely important for the state if it wished to maintain control. State officials quickly became the providers of justice. As discussed previously, the phasing out of duelling and vendetta settling made way for the state to step in and concern themselves with punishment and crime. Although already an issue of the state, capital punishment and the execution theatre became the mainstage for the production of state power. The guilty verdict was often passed in private, while the execution itself remained very public. ${ }^{17}$ This relationship between private and public gave the people the perception that the state was supplying justice to the "guilty." The people relied heavily on this system because they themselves were no longer permitted to handle their issues in the same fashion as they might have in the past. They remained unaware of the events occurring behind closed doors, subjected only to the justice being carried out in the execution.

Infanticide was one crime the state concerned itself with in the sixteenth century. Women were constantly charged, tried, and executed for committing infanticide if their child, unreported and born out of wedlock, died after birth. These convictions were not based on conclusive evidence, as many doctors had a difficult time determining when

\footnotetext{
${ }^{17}$ Muir, 116.
} 
children were born dead or alive. ${ }^{18}$ The trial of Anna Maria Rauin was a questionable one, concerned with the death of her newborn child. The trial, a private matter, proved that doctors were unable to determine if her child was born alive and died afterwards or not. Despite the inconclusiveness of the trial, her confession was enough to prove "that it was the intention of the accused to keep the child from crying by pressing on its throat so that no one would know anything about this birth. ${ }^{, 19}$ Her execution was set to be by the sword, a public affair. The people were not privy to the knowledge of her inconclusive trial, only that she was a child murderess. Executions gave the state the power to be seen to impose justice upon the guilty, a process brought to a resolution with the death of the guilty. ${ }^{20}$

In addition to providing justice, the state used executions to suppress discontent with the justice system. One of the biggest threats of the public rallying behind state authorities was the possibility of "disrupted" executions. For the state, a "good" execution was both public and peaceful. ${ }^{21}$ The power of the state was made public and the crowd was convinced the party being executed was guilty. In order to ensure these death sentences were carried out "peacefully," state-sanctioned Comforters were appointed the duty of tending to the criminal twenty-four hours before their execution time. Their job was to ensure the criminal accepted that he was going to die, by any means possible. They comforted with prayer, song, assurances about God's plan, and the necessity to

\footnotetext{
${ }^{18}$ Merry E. Wiesner-Hanks, "Death Sentence of a Woman Accused of Infanticide, Germany 1740," in Early Modern Europe, 1450-1789 (Cambridge: Cambridge University Press, 2006).

${ }^{19}$ Ibid.

${ }^{20}$ P.J. Klemp, “'He That Now Speaks, Shall Speak No More For Ever': Archbishop William Laud in the Theatre of Execution," The Review of English Studies, New Series, 61, no. 249 (2010): 189.

${ }^{21}$ Terpstra, The Art of Executing Well, 1.
} 
focus on praying for the soul. In Preparing for Execution: Bolognese Comforters'

Manual, section 22, the biggest fear of the state is outlined. The article reads,

Always make him say some prayer so that he does not think, and so that he does not listen to what is being read. And this is because if he were to hear read out some crime that he did not commit, he would get very agitated. And there are times some of them may say to the notary who is reading, 'You are lying through your teeth,' and this is very bad. Firstly, because rage flames up in his heart, and also because he ends up denying everything that is being read and ends up denying the truth. For it's not possible that the notary doesn't say or read something true. Therefore be advised to make sure, if you can, that he does not commit this $\sin ^{22}$

The manual asks the comforter to ensure the convict's mind is not focused on the charges being read, because if he were to shout out in denial against what was being read, there was potential for public outcry as well. As long as the execution remained free from disturbances, the public was kept at bay, and the convicted was executed, the state maintained social order. Following the execution, there was a "subsequent reinstatement of traditional hierarchies and patterns of civilised behaviour." ${ }^{23}$

State authorities used one other tool at their disposal: mercy. Maintaining social order required a give-and-take between mercy and convictions, with respect to death sentences. Not all convictions resulted in death for the guilty party - that would give state authorities a bad reputation and cause considerable unrest amongst the community. Instead, officials decided on appropriate cases where mercy could be afforded. In the case of Antonia Mussona, her case in 1644 was likely dismissed. She petitioned the courts of Parma for an acquittal of the fines she faced for getting into an argument with her neighbour. ${ }^{24}$ In this instance, it was easier for the court to absorb the fine and let Antonia off with a warning than to appear cruel. The use of violence for punishment questioned

\footnotetext{
22 "Preparing for Execution: Bolognese Comforter's Manual."

${ }^{23}$ Klemp, 189.

24 "Excerpts from denunciations and trials in Bologna, 1600-1700."
} 
who had the right to take such actions and when it was legitimately warranted. ${ }^{25}$ The act of mercy in more menial cases made the legitimization of punishment and death sentence convictions easier. Power rested solely with the government to convict worthy criminals with the punishment of death.

This power to convict criminals and sentence them to death also meant the government had a great responsibility to the innocent in the community. The control state authorities had over determining who lived and who died meant protecting those within the community who had not been convicted of any crimes. State governments often tried to refrain from involving themselves with conflicts within the community. However, the inability to carry out vengeance meant that the community relied on officials to settle their differences for them. In November 1494, there was a coup that drove Piero di Lorenzo d'Medici out of Florence. Five men attempted to return Piero to the city in 1497 but were caught before their plan could take hold. They were executed by the Florentine government, the first political execution in Florence since $1481 .^{26}$ This marked the beginning of an increase of political executions, as members of the elite relied more heavily on state-sanctioned executions. Execution insured the safety of the community and more importantly of the elite; it provided safety of their persons, as well as their reputations. Despite their avoiding involving themselves in issues of conflict, states made issues of the community, like punishment and retribution, a priority.

Issues of the community also included honour. State authorities used the whole execution process as a means of restoring honour in the community it represented. After a

\footnotetext{
${ }^{25}$ Susan Dwyer Amussen, "Punishment, Discipline, and Power: The Social Meanings of Violence in Early Modern England," Journal of British Studies 34, no. 1 (1995): 4.

${ }^{26}$ Nicholas Scott Baker, "For Reasons of State: Political Executions, Republicanism, and the Medici in Florence, 1480-1560," Renaissance Quarterly 62, no. 2 (2009): 444-445.
} 
guilty conviction, the criminal was placed in a prison cell to await his execution date. Prisons provided answers for every party involved with the criminal: the state's concerns for public order were put at ease with the private confinement of the criminal, away from the public eye, and families' problems of "honour [were] no longer put in jeopardy by the deviant behaviour of a family member. ${ }^{27}$ The final part of the process, the execution itself, physically removed the dishonour held by the individual from the community. By disposing of individuals within a community who did not hold the required honour to partake in a community, state powers maintained their own honour in the eyes of residents. Thus, honour was used as a double function: remove the dishonour of the individual and increase the honour of the state, making it more favourable to the people. In the early modern era, the public perception people had of the government determined the government's overall honour. As long as the state wished to maintain authority, it needed to maintain the status of "honourable" in the eyes of its people. In the case of honour, it was important for the people of a community to both interact with honourable people as well as be governed by an honourable authority.

Maintaining social order and caring for public interests boiled down to how frequently the state ordered executions. The frequency of such convictions was a product of their time and place, varying geographically throughout the entire early modern era. Initially, gallows and criminal burials were located on state boundaries and at city gate entrances, serving to demonstrate judicial status and as a warning to travellers and subordinates to be mindful of their conduct. ${ }^{28}$ The sight of hanged bodies was a familiar

\footnotetext{
${ }^{27}$ Pieter Spierenburg, The Prison Experience: Disciplinary Institutions and Their Inmates in Early Modern Europe (Amsterdam: Amsterdam University Press, 2007).

${ }^{28}$ Joris Coolen, "Places of Justice and Awe: the Topography of Gibbets and Gallows in Medieval and Early Modern North-Western and Central Europe," World Archaeology 45, no. 5 (2013): 766.
} 
one, at least until the early seventeenth century. Figure 1.2 shows the gradual decrease in frequency of executions in Bologna throughout the seventeenth century. ${ }^{29}$

As time progressed, popular support for public execution began to diminish. Community acceptance of public violence changed throughout the seventeenth century, gradually making it a highly contested act. This century saw a major shift in stateadministered violence becoming a regularly private event, rather than public. The diminishing of public violence contributed to the pacification of Europe during this time $;{ }^{30}$ but it also meant a continuation of state authority. The fading popularity of executions was a reflection of community concerns regarding public executions, however, the state was still able to conduct executions as it saw fit. Executions were thus used to show that the state remained in control when a criminal committed certain crimes, despite the growing discomfort amongst the public. Criminals were still used as examples to maintain social order and remind the public who was in charge.

The frequency and timing of executions also represented a government's ability to maintain power during particular times of unrest. During Queen Elizabeth I's reign, England saw 6160 victims hanged at Tyburn. ${ }^{31}$ Elizabeth did not do away with public executions because of changing public perceptions, but instead used these 6160 criminals to maintain control over her subjects. Elizabethans were fearful of taking action against the state. Executions were just one way the Queen kept her subjects in line and maintained social order. Figure 1.2 also shows the ability of the Bolognese state to maintain power during some difficult years. There are a few outlying years, namely 1609 ,

\footnotetext{
${ }^{29}$ Archivio di Stato di Bologna.

${ }^{30}$ Julius R. Violence in Early Modern Europe, 1500-1800 (Cambridge: Cambridge University Press, 2001).

${ }^{31}$ Molly Smith, "The Theater and the Scaffold: Death as Spectacle in The Spanish Tragedy," Studies in

English Literature, 1500-1900 32, no. 2 (1992): 217-232.
} 
$1625,1630,1643$, and 1644 with exceptionally high numbers of executions. In these years, there would have been a higher crime rate than usual, requiring more state intervention. That being said, it might be more appropriate to look at outlying years with lower numbers. 1653 saw a spike in executions to 11 from 7 the previous year, presumably due to a higher-than-normal crime rate, or a necessity to exert state power more heavily. In any case, this outlying year represents the Bolognese state's ability to maintain control over its people in a time when people were acting in disregard of the law.

\section{Conclusions}

Although the early modern era saw many changes, one of the biggest was the use of violence and punishment in conviction of criminals. On the surface, execution provided many outlets for the public. The age of vendettas disappeared quickly towards the end of the sixteenth and early seventeenth centuries, forcing a reliance upon the state for support in acquiring justice. The restoration of honour and religious salvation of the community were two by-products of the pageantry of execution. The processes of conviction and death set the community right again, restoring justice and allowing the community to continue to function as it normally would. The state played a major role in facilitating the peace of the community by involving itself with the conflict occurring between two individuals and between individuals and the state. This involvement was not selfless by any means. The state used public executions to maintain its control over a community of people. It sought to use execution as a reminder of social structure and social order, of the power imbalance between it and the people. The show of death on the 
mainstage of the city or rural area exhibited a sense of state superiority, especially during times of unrest or particularly high crime rates. State authorities appeared merciful in order to gain favour with the communities they ruled, but utilized execution to balance their benevolence and ensure there remained just enough fear to maintain order.

Execution was a function of the state and community that changed over time. It served to comfort the community while ensuring dominance of state authorities. The spectacle of death that surrounded executions illustrates a dependency on public opinion to rule the population. States required the support, as well as fear, of the community they governed in order to maintain control over the public. Execution was one element of daily life manipulated by state powers to, in turn, maintain control over other aspects of life. Its usefulness was directly dependent upon the geographical place and time during the early modern era. Execution was a messy necessity of the state system, ultimately allowing governments to maintain control of, and appease, the people they presided over. 


\section{Appendix 1}

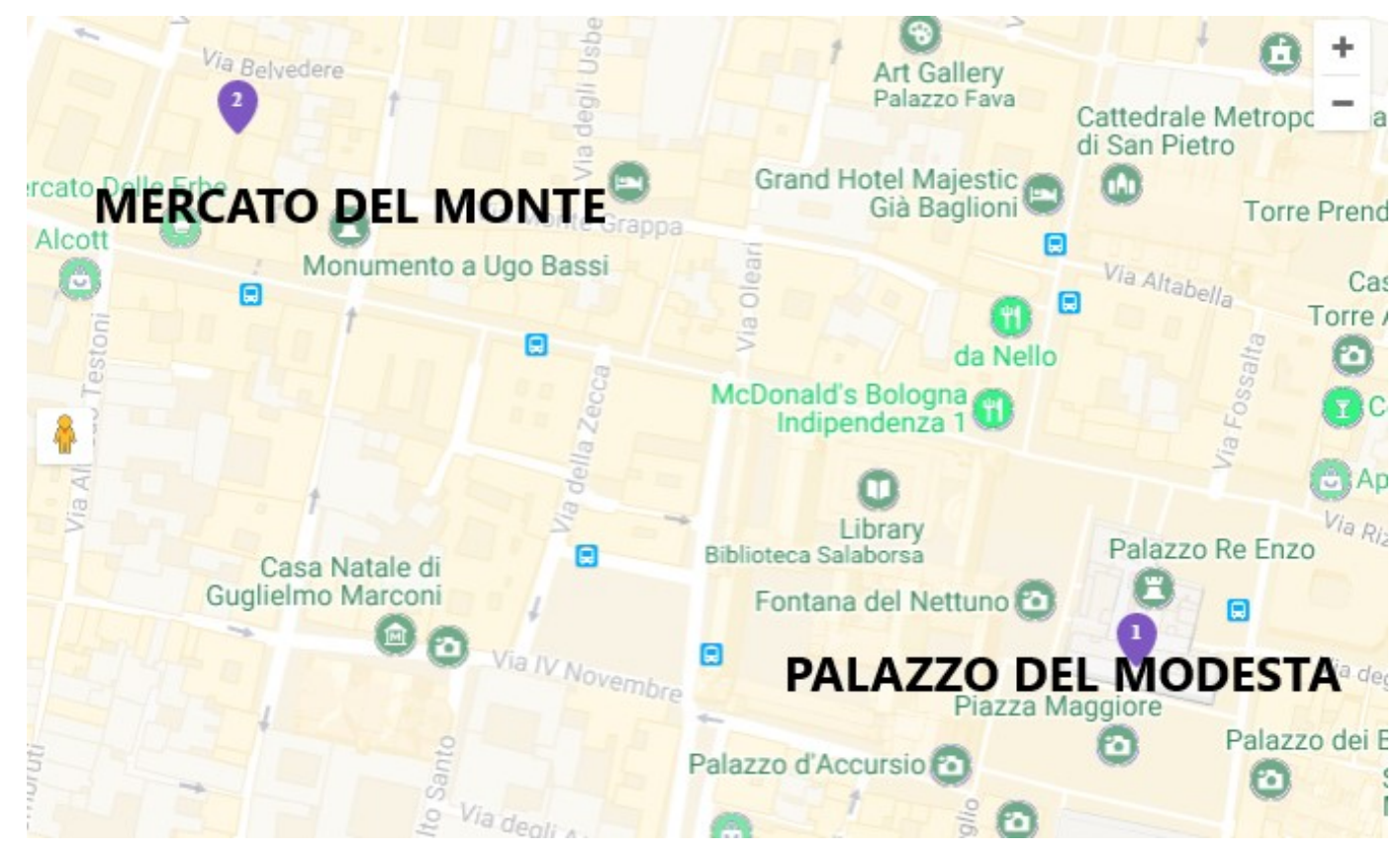

Figure 1.1: Start and Finish of Prisoner Procession

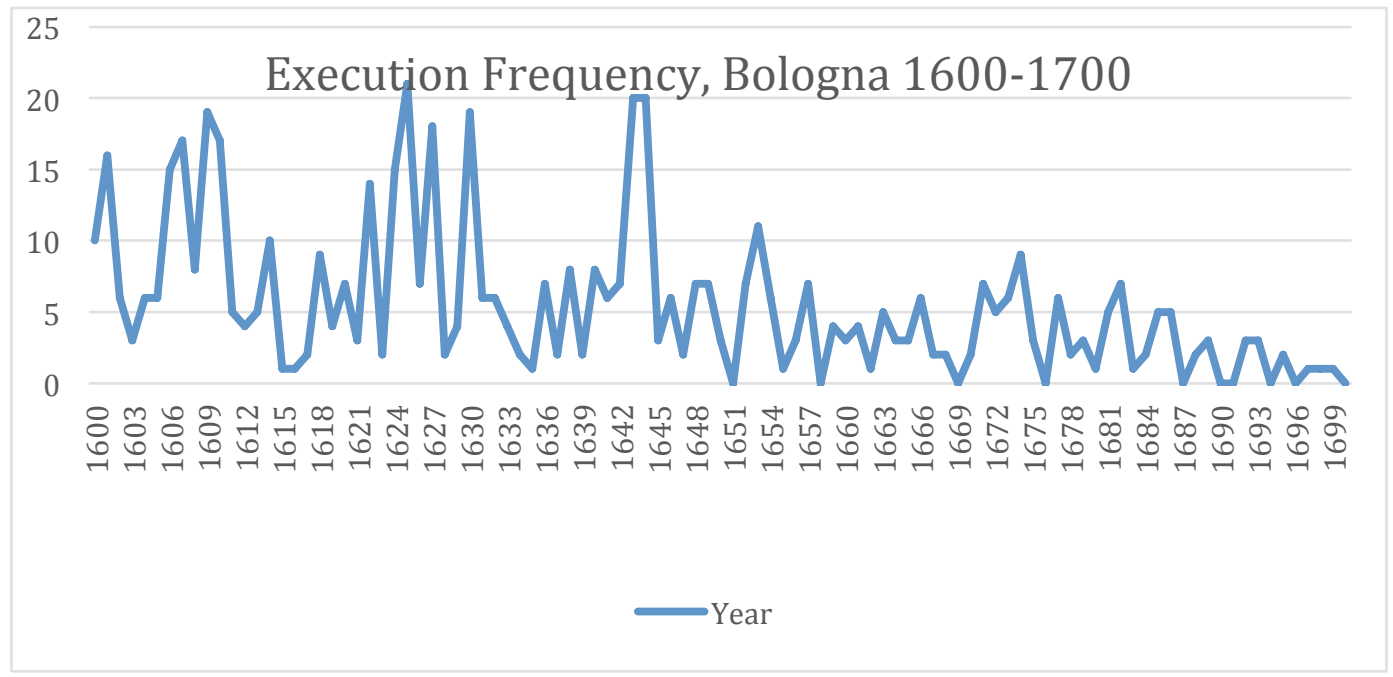

Figure 1.2: Number of Executions in Bologna, 1600-1700 


\section{Bibliography}

Amussen, Susan Dwyer. "Punishment, Discipline, and Power: The Social Meanings of Violence in Early Modern England." Journal of British Studies 34, no. 1 (1995): 134.

Archivio di Stato di Bologna, Gonari delle Giustizie seguite in Bologna del 1050-1730.

Baker, Nicholas Scott. "For Reasons of State: Political Executions, Republicanism, and the Medici in Florence, 1480-1560." Renaissance Quarterly 62, no. 2 (2009): 444478.

Coolen, Joris. "Places of Justice and Awe: The Topography of Gibbets and Gallows in Medieval and Early Modern North-Western and Central Europe." World Archaeology 45, no. 5 (2013): 762-779.

Cunningham, Karen. "Renaissance Execution and Marlovian Elocution: The Drama of Death.” PMLA 105, no. 2 (1990): 209-222.

"Death Sentence of a Woman Accused of Infanticide, Germany 1740." In Early Modern Europe, 1450-1789, ed. Merry E. Wiesner-Hanks. Cambridge: Cambridge University Press, 2006.

http://www.cambridge.org/features/wiesnerhanks/primary_sources.html

"Excerpts from denunciations and trials in Bologna, 1600-1700."

Harrington, Joel F. “Lord Judge, Have I Executed Well?” Slate Magazine. 30 May 2013, accessed 24 November 2017.

http://www.slate.com/articles/news_and_politics/history/2013/05/executioners_in medieval_europe_history_of_capital_punishment.html.

Hughes, Steven. "Fear and Loathing in Bologna and Rome: The Papal Police in Perspective.” Journal of Social History 21, no. 1 (1989): 97-116.

Klemp, P.J. “'He That Now Speaks, Shall Speak No More For Ever': Archbishop William Laud In The Theatre Of Execution." The Review of English Studies 61, no. 249 (2010): 188-213.

Merback, Mitchell B. The Thief, the Cross and the Wheel: Pain and the Spectacle of Punishment in Medieval and Renaissance Europe. London: Reaktion, 2001.

Muir, Edward. Ritual in Early Modern Europe. Cambridge: Cambridge University Press, 2005.

"Preparing for Execution: Bolognese Comforter's Manual."

"Punishment of a Woman for Theft and Prostitution, Germany $16^{\text {th }}$ century." In Early Modern Europe, 1450-1789, ed. Merry E. Wiesner-Hanks. Cambridge: Cambridge University Press, 2006.

http://www.cambridge.org/features/wiesnerhanks/primary_sources.html

Ruff, Julius R. Violence in Early Modern Europe, 1500-1800. Cambridge: Cambridge University Press, 2001.

Smith, Molly. "The Theater and the Scaffold: Death as Spectacle in The Spanish Tragedy." Studies in English Literature, 1500-1900 32, no. 2 (1992): 217-32. 
Schmidt, Franz, A Hangman's Diary: Being the Journal of Master Franz Schmidt, public executioner of Nuremberg, 1573-1617. Montclair, NJ: Patterson Smith, 1973.

Spierenburg, Pieter. The Prison Experience: Disciplinary Institutions and Their Inmates in Early Modern Europe. Amsterdam: Amsterdam University Press, 2007.

Spierenburg, Pieter. Violence and Punishment: Civilizing the Body Through Time. Cambridge: Polity Press, 2013.

Terpstra, Nicholas. "Body Politics: The Criminal Body between Public and Private." Journal of Medieval and Early Modern Studies 45, no. 1 (2015): 7-52.

Terpstra, Nicholas. The Art of Executing Well: Rituals of Execution in Renaissance Italy. Kirksville, Mo.: Truman State University Press, 2008. 